\title{
An insight into anti-adipogenic properties of an Oroxylum indicum (L.) Kurz extract
}

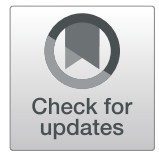

Tanaporn Hengpratom ${ }^{1}$, Gordon M. Lowe $2^{2^{*}}$ and Griangsak Eumkeb ${ }^{1^{*}}$ (D)

\begin{abstract}
Background: Oroxylum indicum fruit extract (OIE) has been reported to inhibit the development of adipocytes. However, the exact mechanism of its metabolic activity is not clearly defined. This study attempted to investigate whether OIE was involved in disrupting the cell cycle, glucose metabolism, and mitochondrial function in 3 T3-L1 cells.

Methods: The effect of the OIE on cell cycle progression was measured by flow cytometry along with observing the expression of the cycle regulator by immunoblotting. The effect of the OIE on glucose metabolism was investigated. The amount of glucose uptake (2-NBDG) influenced by insulin was determined as well as the protein tyrosine phosphorylation (PY20), and glucose transporter4 (GLUT4) expression was determined by immunoblotting assay. Mitochondria are also essential to metabolic processes. This study investigated mitochondrial activity using fluorescent lipophilic carbocyanine dye (JC-1) and mitochondria mass by MitoTracker Green (MTG) staining fluorescence dyes. Finally, cellular ATP concentration was measured using an ATP chemiluminescence assay.

Results: Treatment with OIE plus adipogenic stimulators for $24 \mathrm{~h}$ arrested cell cycle progression in the G2/M phase. Moreover, $200 \mu \mathrm{g} / \mathrm{mL}$ of OIE significantly diminished the expression of the insulin receptor (IR) and GLUT4 protein compared to the untreated-adipocytes $(P<0.05)$. The mitochondrial membrane potential (MMP) was significantly reduced $(24 \mathrm{~h}$ ) and increased (day 12$)$ by OIE compared to untreated-adipocytes $(P<0.05)$. However, OIE maintained MMP and ATP at a similar level compared to the pre-adipocytes (day 12). Transmission electron microscope (TEM) results demonstrated that OIE could protect mitochondria deformation compared to the untreated-adipocytes.
\end{abstract}

Conclusion: These results suggest that the inhibitory effect of the OIE on adipogenesis may potentially inhibit the cell cycle and phosphorylation of IR, leading to a decrease in glucose uptake to the cells. The OIE also slows down the mitochondrial activity of the early phase of cell differentiation, which can also inhibit the development of fat cells.

Keywords: Oroxylum indicum extract, Adipogenesis, 3 T3-L1, Glucose transporter 4, Mitochondrial membrane potential

\footnotetext{
* Correspondence: G.M.Lowe@ljmu.ac.uk; griang@sut.ac.th

${ }^{2}$ School of Pharmacy and Biomolecular Sciences, Liverpool John Moores

University, Liverpool L3 3AF, UK

${ }^{1}$ School of Preclinic, Institute of Science, Suranaree University of Technology,

Nakhon Ratchasima 30000, Thailand
}

(c) The Author(s). 2020 Open Access This article is licensed under a Creative Commons Attribution 4.0 International License, which permits use, sharing, adaptation, distribution and reproduction in any medium or format, as long as you give appropriate credit to the original author(s) and the source, provide a link to the Creative Commons licence, and indicate if changes were made. The images or other third party material in this article are included in the article's Creative Commons licence, unless indicated otherwise in a credit line to the material. If material is not included in the article's Creative Commons licence and your intended use is not permitted by statutory regulation or exceeds the permitted use, you will need to obtain permission directly from the copyright holder. To view a copy of this licence, visit http://creativecommons.org/licenses/by/4.0/. The Creative Commons Public Domain Dedication waiver (http://creativecommons.org/publicdomain/zero/1.0/) applies to the data made available in this article, unless otherwise stated in a credit line to the data. 


\section{Background}

3 T3-L1 pre-adipocytes differentiation model has been extensively used for the study of adipogenesis [1]. The progression of $3 \mathrm{~T} 3-\mathrm{L} 1$ pre-adipocytes to adipocytes is initiated by various stimulators, which include 3isobutyl-1-methylxanthine (IBMX), dexamethasone (DEX), and insulin. Once the cells receive these stimulators, they proliferate to confluence. Post-confluent preadipocytes become growth-arrested at the G1/S phase of the cell cycle [2]. The re-entry of growth-arrested preadipocytes into the cell cycle and the completion of several rounds of clonal expansion are the initial steps in the process of adipogenesis [3].

Adipocytes differentiation is marked by a change in the expression of many receptors on the plasma membrane. One such change is the increased expression of receptor glucose transporters, particularly GLUT4 [4]. Binding of the insulin to its receptor initiates a signaling cascade results in the translocation of GLUT4 to the plasma membrane, which leads to the facilitated diffusion of glucose into the cell [5]. Additionally, most of the adenosine triphosphate (ATP) synthesized during glucose metabolism is produced in the mitochondria through oxidative phosphorylation [6]. The previous study found that 20 to 30 fold of mitochondrial protein was increased during the differentiation of 3 T3-L1 cells, together with increased expression of lipogenic enzymes [7]. As mentioned, glucose synergizes with insulin and mitochondria function, and all three are an important factor for the lipogenic pathway.

The OIE was previously reported as having antiadipogenic properties. Studies revealed that when preadipocytes were subjected to the adipogenic stimulators along with $200 \mu \mathrm{g} / \mathrm{mL}$ of OIE during the early phases of the adipocyte differentiation process, it significantly inhibited the accumulation of lipids and prevented the transformation to adipocytes [8]. These results led us to believe that OIE may influence the preliminary stages of adipocyte development. OIE can inhibit the expression of Peroxisome proliferator-activated receptor $\gamma^{2}$ (PPAR $\gamma 2$ ), leading to decreased expression of adipokine and lipogenic enzymes [9]. This study intended to investigate the role of OIE on the cell cycle, glucose metabolism, and mitochondrial function in the $3 \mathrm{~T} 3-\mathrm{L} 1$ cell during adipogenesis.

\section{Methods}

Plant collections, authentication, and liquid chromatography-mass spectrometry (LC-MS) characterization

The fruits of Oroxylum indicum (L.) Kurz, family Bignoniaceae $(O$. indicum) were purchased from the Wang Nam Khiao District, Nakhon Ratchasima province, Thailand, from July to September 2015. Herbarium voucher specimens from all parts of this plant were prepared and authenticated by Dr. Santi Wattatana, a lecturer and a plant biologist at the Institute of Science, Suranaree University of Technology, Thailand. The voucher specimens (SOI0808U) were deposited at Suranaree University of Technology. Fresh fruits of O. indicum with seeds were cut into small pieces and dried in the oven at $40^{\circ} \mathrm{C}$. Then, air-dried fruits were ground into a powder with an electric grinder. $500 \mathrm{~g}$ of dry powder was extracted with $95 \%$ ethanol by a soxhlation for $8 \mathrm{~h}$. The extract was then filtered through Whatman No. 1 filter paper. Next, the ethanolic filtrate was concentrated using a vacuum rotary evaporator $\left(50^{\circ} \mathrm{C}\right)$ and dried by lyophilization to give crude dried extracts of $O$. indicum. Crude dried extracts were stored at $-20^{\circ} \mathrm{C}$ until use. In cell culture experiments, the OIE was dissolved in $100 \%$ dimethyl sulfoxide (DMSO) and then diluted to $0.1 \%(\mathrm{v} /$ v) DMSO in cell culture medium when preparing the designated concentrations (50 to $200 \mu \mathrm{g} / \mathrm{mL}$ ).

For LC-MS analysis, the constituents of the whole fruit OIE had been investigated following the method of Hengpratom et al. with some modifications [9]. Briefly, the OIE was dissolved in the methanol at concentrations 20 and $10 \mathrm{mg} / \mathrm{mL}$. The experiment was performed on the Dionex Ultimate 3000 UHPLC system (Dionex, USA) coupled with electrospray ionization (ESI) tandem mass spectrometer (micro-TOF-QII) (Bruker, Germany). The optimum separation was achieved with a Zorbax SBC18 column $(250 \mathrm{~mm} \times 4.6 \mathrm{~mm} \times 3.5 \mu \mathrm{m})$ (Agilent Technologies, USA) with a flow rate of $0.8 \mathrm{~mL} / \mathrm{min}$ of the mobile phase, which comprised $0.1 \%$ formic acid in deionized water (solvent $\mathrm{A}$ ) and acetonitrile acid (solvent B). The gradient program was starting from $30 \%$ B to $80 \% \mathrm{~B}$ in $30 \mathrm{~min}$ and stayed at $80 \% \mathrm{~B}$ until $38 \mathrm{~min}$, then the gradient program was adjusted to $30 \% \mathrm{~B}$ in $2 \mathrm{~min}$ and stayed until the run ending at $45 \mathrm{~min}$. The injection volume of all samples was $5 \mu \mathrm{L}$. The results were obtained in a mass scanning mode in the range of $50 \mathrm{~m} / \mathrm{z}$ to $1500 \mathrm{~m} / \mathrm{z}$ at negative ion polarity. Nebulizer gas was 2 Bar, dry gas, and temperature were set to $8 \mathrm{~L} / \mathrm{min}$ and $180^{\circ} \mathrm{C}$; the capillary voltage was $4.5 \mathrm{kV}$. The calibration curves of the reference standards were obtained from the concentration ranges between $0.5 \mu \mathrm{g} / \mathrm{mL}$ to $250 \mu \mathrm{g} /$ $\mathrm{mL}$, and the concentration of targeted compounds was calculated using the equation for linear regression obtained from the calibration curves.

\section{Adipocytes differentiation and treatment}

The $3 \mathrm{~T} 3-\mathrm{L} 1$ pre-adipocytes cell line was purchased from American Type Culture Collection (ATCC, Manassas, VA, USA). The differentiation protocol was derived from a previous study [10]. At 2 days following confluence (day 0), the cells were stimulated to differentiate with Dulbecco's Modified Eagle Medium (DMEM) containing 
$10 \%$ fetal bovine serum (FBS) (Hyclone, Logan, UT, USA), 1.0 $\mu \mathrm{M}$ of dexamethasone (G Bioscience, St. Louis, MO, USA), $0.5 \mathrm{mM}$ of IBMX and $1.0 \mu \mathrm{g} / \mathrm{mL}$ of insulin for 2 days. From day 4 onwards, the differentiation media were replaced by $10 \%$ FBS/DMEM media containing $1.0 \mu \mathrm{g} / \mathrm{mL}$ of insulin. These media were changed every 2 days until the cells were harvested. All media contained $100 \mu \mathrm{g} / \mathrm{mL}$ of streptomycin and $100 \mathrm{U} / \mathrm{mL}$ of penicillin (GIBCO). Cells were maintained at $37^{\circ} \mathrm{C}$ in a $95 \%$ humidified with $5 \%$ of $\mathrm{CO}_{2}$ atmosphere.

For the treatment of $3 \mathrm{~T} 3-\mathrm{L} 1$ cells, the cells were seeded in a 6-well plate at the density of $1.5 \times 10^{5}$ cells/ well. The cells were allowed to adhere to the plate for $48 \mathrm{~h}$ and were then divided into 6 groups; 1$)$ nondifferentiated cells (pre-adipocytes, ND); 2) differentiated cells treated with $0.1 \%$ DMSO (untreated-adipocytes, D); 3-6) differentiated cells treated with 50, 100, 150, and $200 \mu \mathrm{g} / \mathrm{mL}$ OIE (OIE-treated adipocytes, D + OIE), respectively. The different concentrations of OIE were diluted to get $0.1 \%(\mathrm{v} / \mathrm{v})$ DMSO in cell culture media and treated throughout the differentiation period until the cells were harvested. Twenty-four hours after the cells were induced to differentiate. The cells were collected for cell cycle analysis and protein quantification. For additional experiments, the cells were collected on day 12 for protein quantification, immunocytochemistry, flow cytometry, and TEM analysis.

\section{Cell cycle analysis}

Post confluent 3 T3-L1 pre-adipocytes were stimulated by the differentiated media in the absence and presence of OIE (50 to $200 \mu \mathrm{g} / \mathrm{mL}$ ) for $24 \mathrm{~h}$. The cells were collected by trypsinization and washed twice with phosphate-buffered saline (PBS). The cells were then fixed in $80 \%$ of ethanol and stored at $-20^{\circ} \mathrm{C}$ for $1 \mathrm{~h}$. The fixed cells were washed twice with ice-cold PBS. The cells were treated with $50 \mu \mathrm{L}$ of RNaseA ( 0.1 unit/ $\mathrm{mL})$ and $150 \mu \mathrm{L}$ of Propidium iodide (PI) $(50 \mu \mathrm{g} / \mathrm{mL})$ at $37^{\circ} \mathrm{C}$ for $1 \mathrm{~h}$. The fluorescence intensity of the PI stained cells was measured using the BD Accuri C6 flow cytometer. The data from 25,000 cells per sample were analyzed using FlowJo software and the Dean-Jett-Fox model.

\section{Protein extraction and immunoblot analysis}

The expression of cyclin-dependent kinase (Cdk2), PY20, and GLUT4 proteins in control and OIE-treated cells was determined by Western immunoblotting. The lysates $(50 \mu \mathrm{g}$, each) were separated on $12 \%$ MiniPROTEAN TGX stain-free pre-cast gels. After electrophoresis, the proteins were transferred to polyvinylidene difluoride (PVDF) using the Trans-Blot Turbo system (Bio-Rad, Watford, UK). The membranes were then blocked with $5 \%$ skimmed milk for $1 \mathrm{~h}$ at room temperature, followed by a washing step. The membranes were subsequently incubated with mouse monoclonal antibody (anti-Cdk2, anti-PY20, and anti-GLUT4) (1:1000 in PBS), overnight at $4{ }^{\circ} \mathrm{C}$. After extensive washing, the membranes were incubated with mouse IgGk light chain binding protein (m-IgGK BP) conjugated to horseradish peroxidase (HRP) (1:3000 in PBS) for $1 \mathrm{~h}$ at room temperature, followed by washing with PBS with $0.1 \%$ Tween 20 (PBST). The antigen-antibody complex was developed using enhanced chemiluminescence (ECL) substrate solution for 5 min (Bio-Rad, Watford, UK). The intensities of the adiponectin protein bands were quantified using ImageJ software. The data were normalized using $\beta$-actin as an internal control.

\section{Immunocytochemistry}

On day 12, $3 \mathrm{~T} 3-\mathrm{L} 1$ pre-adipocytes and adipocytes were collected, washed with cold PBS, fixed for $15 \mathrm{~min}$ in cold acetone, and washed with PBST. After blocking with $4 \%$ of bovine serum albumin (BSA) for $1 \mathrm{~h}$ at room temperature, the cells were washed and incubated with anti-GLUT4 antibody (1:200 in PBS) overnight at $4{ }^{\circ} \mathrm{C}$. After extensive washing, mouse IgGk conjugated with fluorescein isothiocyanate (FITC) (1:500) was applied to the samples and incubated for $90 \mathrm{~min}$ at room temperature. After washing thoroughly with PBS, the cells were double-stained with 4',6-Diamidino-2-Phenylindole (DAPI) (nucleus stain) (1:1000) for $5 \mathrm{~min}$ in the dark and washed twice with PBS. Finally, the cells were visualized using fluorescence microscopy (Leica DMI6000B).

\section{Flow cytometry}

Flow cytometry was used to detect glucose concentration and mitochondria activity in $3 \mathrm{~T} 3-\mathrm{L} 1$ cells. At $24 \mathrm{~h}$ after inducing cells with the differentiation media and on day 12, the cells were collected and washed twice with PBS. Then, cells were incubated with fluorescence dye for $60 \mathrm{~min}$, including $0.1 \mathrm{mM}$ of 2-NBD-Glucose (2NBDG) for glucose uptake and $10 \mu \mathrm{M}$ of JC-1 for MMP. Next, cells were washed twice with PBS. Labeled cells were collected (keep in the dark) and analyzed using a flow cytometer with excitation $488 \mathrm{~nm}$. All data were recorded and analyzed using BD accuri C6 software. The data were presented as the median fluorescent signals for 10,000 cells.

\section{Confocal microscopy}

The MitoTracker green fluorescent dye was used to label mitochondria within 3 T3-L1 cells. On day 12, the culture media were removed, and the cells were incubated with $200 \mathrm{nM}$ of MitoTracker green fluorescent dye for $45 \mathrm{~min}$ at $37^{\circ} \mathrm{C}$. Then, the cells were carefully washed with culture media and trypsinized. Labeled cells were 
separated and deposited onto a Shandon cytoslide glass slide by using Shandon cytospin 4 cytocentrifuge, following manufactured protocol (Thermo Fisher Scientific). Briefly, $200 \mu \mathrm{L}$ of each sample was loaded in the Shandon cytofunnel chamber and spun at $1000 \mathrm{rpm}$ for $5 \mathrm{~min}$ to allow for complete fluid absorption. The cells were allowed to dry at room temperature, and the mounting medium was applied to the surface of the slide along with a cover slide. The images were obtained using a Zeiss 510 Meta laser scanning microscope mounted on an Axiovert $200 \mathrm{M}$ BP computer-controlled inverted microscope. The Argon ion laser was used with an excitation wavelength of $488 \mathrm{~nm}$, and the images were captured at $\times 100$ and $\times 200$ magnification.

\section{ATP measurement}

ATP level was measured as previously described with some modifications [11]. On day 12 , the media were removed, and the cells were washed twice with $1 \mathrm{M}$ of cold PBS. The level of ATP released was then determined using the ATP bioluminescent somatic cell assays kit (Sigma-Aldrich, Dorset, UK). Fifty microliter of ATP releasing reagent stock with $450 \mu \mathrm{L}$ of ultrapure water was added directly to the cells and incubated for $5 \mathrm{~min}$. Then, $20 \mu \mathrm{L}$ of mixed samples were taken to the 96 well plates, followed by adding $80 \mu \mathrm{L}$ of ultrapure water. Finally, $100 \mu \mathrm{L}$ of the luciferase assay mix was added to the sample. The amount of light emission was then measured using a microplate luminometer. ATP concentration ( 0 to $200 \mathrm{nmol} / \mathrm{L}$ ) was determined from the standard curve. The protein concentrations in each well were used to normalize the ATP content $(\mathrm{nM} / \mathrm{mg}$ of protein).

\section{Transmission electron microscopy}

On day 12 , the cells were dissociated with $0.25 \%$ trypsin at $37^{\circ} \mathrm{C}$ for $3-5 \mathrm{~min}$, and the digestion was stopped with a culture medium containing FBS. The cells were transferred into a $10 \mathrm{~mL}$ tube, centrifuged at $1200 \mathrm{rpm}$ for 8 min. They were washed with PBS $\left(4{ }^{\circ} \mathrm{C}\right)$ and then centrifuged at $1200 \mathrm{rpm}$ for a further $8 \mathrm{~min}$. After discarding the supernatant, $2.5 \%$ glutaraldehyde in $0.1 \mathrm{M}$ phosphate buffer was added to the cells and left to fix at $4{ }^{\circ} \mathrm{C}$ overnight. The cells were rinsed three times with $0.1 \mathrm{M}$ phosphate buffer ( $\mathrm{pH}$ 7.2) for $15 \mathrm{~min}$ each, followed by post-fixation with $1 \%$ Osmium tetroxide $\left(\mathrm{OsO}_{4}\right)$ prepared in $\mathrm{dH}_{2} \mathrm{O}$. Fixed samples were dehydrated, embedded in epoxy resin (Electron Microscopy Sciences), and polymerized at $60{ }^{\circ} \mathrm{C}$ for $24 \mathrm{~h}$. The blocks were ultrathin-sectioned at $60 \mathrm{~nm}$ with a diamond knife using an RMC ultra-microtome. The sections were placed on copper grids and stained with $2 \%$ uranyl acetate at room temperature for $15 \mathrm{~min}$ and then rinsed with distilled water, followed by secondary staining with lead stain solution (SPI-CHEM) at room temperature for $15 \mathrm{~min}$. The grids were observed under a TEM (FEI Model TECNAI G2 20S-TWIN) at an acceleration voltage of 120 $\mathrm{kV}$.

\section{Statistical analysis}

All the data were expressed as the mean \pm standard deviation of the mean (Mean $\pm \mathrm{SD}$ ). The difference values between cell population in the cell cycle, Cdk2 expression, PY20, and GLUT4 proteins, glucose metabolism uptake, mitochondrial activity, MMP, and ATP production compared between groups were analyzed using oneway analysis of variance (ANOVA) with a Tukey's HSD post-hoc test (SPSS v 23). Values were considered statistically significant when $P<0.05$. The experiments were performed in three independent experiments (each run triplicate). However, the experiments of cells staining (Figs. 5, 7, and 10) and TEM (Fig. 11) were performed in two independent experiments (each run triplicate).

\section{Results}

Liquid chromatography-mass spectrometry analysis

This study examined the presence of key flavones and associated compounds in OIE. The mass spectral data of the reference compounds and sample can be seen in Fig. 1 and the content in Table 1. The major components of OIE had composed of 1) luteolin 2) apigenin 3) baicalein, and 4) oroxylin A (Fig. 1). The profiles of these compounds were compared to authentic standards. The most dominant flavonoid in OIE was baicalein; indeed, $20 \mathrm{mg} / \mathrm{mL}$ of OIE contains $509.96 \mu \mathrm{g} / \mathrm{mL}$ of baicalein (Table 1). In addition, low amount of oroxylin A $(5.33 \mu \mathrm{g} / \mathrm{mL})$, luteolin $(4.20 \mu \mathrm{g} / \mathrm{mL})$, and apigenin $(1.55 \mu \mathrm{g} / \mathrm{mL})$ were also detected in OIE. Moreover, there are two major unknown compounds, including unknown1 (peak 20) and unknown2 (peak 21) (Fig. 1, Table 1). The spectral result of peak 21 showed at $\mathrm{m} / \mathrm{z}$ 254 , which is consistent with the standard chrysin peak [13]. In the same way, the study of Rojsanga reported that $O$. indicum seed extract contained 3 major compounds, including baicalein, baicalin, and chrysin [14]. Thus, a peak 21 could be the chrysin. However, further investigation is needed.

\section{Effect of OIE on inhibition of cell cycle progression}

The effect of the OIE on the cell cycle of 3 T3-L1 cells is shown in Fig. 2a and b. When 3 T3-L1 pre-adipocytes were induced to differentiate with adipogenic stimulators, the cells enter into $\mathrm{S}$ and G2/M phase within $24 \mathrm{~h}$ following induction (Fig. 2a). Further analysis revealed that differentiated cells transformed from G1 and S phase to the G2 phase (36\% cells in G2 phase). In contrast, treatment with OIE at concentrations ranging from 50 to $200 \mu \mathrm{g} / \mathrm{mL}$ significantly arrested cells in the G0/G1 


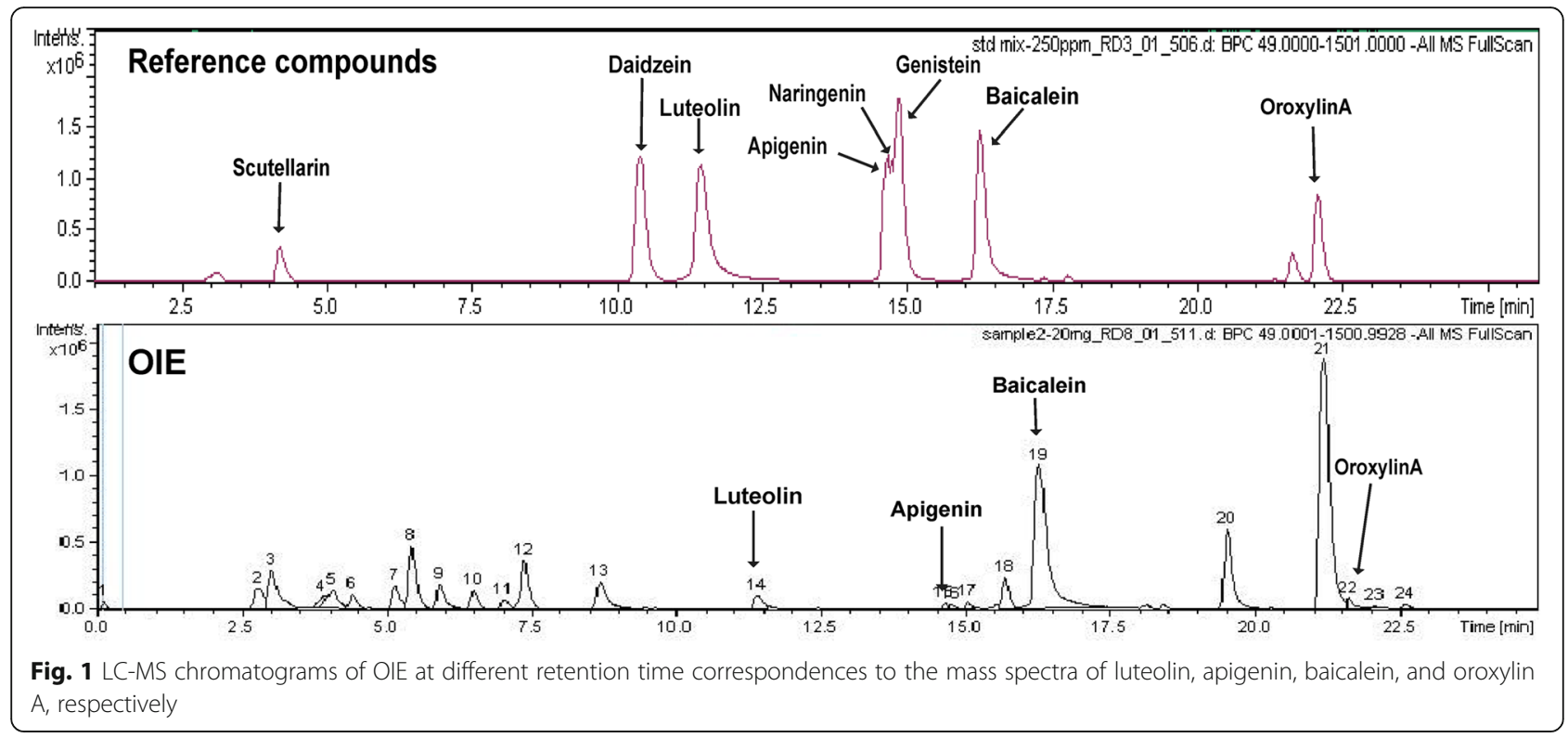

phase $(10.3,10.8,14.4$, and $18.7 \%$ cells in G2 phase, respectively) compared to controls $(P<0.05)$ (Fig. 2a and b). The impact of the OIE on the cell cycle was further explored, and the expression of Cdk2 in differentiating cells was affected at the doses of 150 and $200 \mu \mathrm{g} / \mathrm{mL}$ (Fig. $3 \mathrm{a}$ and $\mathrm{b}$ ). These results suggest that OIE may inhibit cell cycle entry into the G2/M phase of $3 \mathrm{~T} 3-\mathrm{L} 1$ cells. OIE has the potential to inhibit the initiation of mitotic clonal expansion (MCE), which is a significant step for cell differentiation. Thus, this mechanism may play an important role in the suppression of adipogenesis.

\section{Effect of OIE on glucose metabolism}

The effect of the OIE on glucose metabolism was determined by evaluating the expression of GLUT4, the impact on the 2-NBDG uptake, and the PY20 in differentiating $3 \mathrm{~T} 3-\mathrm{L} 1$ cells. The addition of $1.0 \mu \mathrm{g} / \mathrm{mL}$ of insulin in the media-induced the tyrosine phosphorylation of three major proteins with apparent molecular masses of $181(\mathrm{PY} 20(\mathrm{H}))$, $164(\mathrm{PY} 20(\mathrm{H}))$, and $91 \mathrm{kDa}$ (PY20(L)), respectively at both $24 \mathrm{~h}$ and 12 days following differentiation (Fig. 4a and b). These proteins were consistent with insulin activity $[15,16]$. However, phosphorylation proteins PY20(L) and GLUT4 at $24 \mathrm{~h}$ showed no significant difference among the preadipocytes, untreated-adipocytes, and the $200 \mu \mathrm{g} / \mathrm{mL}$ of OIE $(P>0.05)$. After 12 days, there were significantly reduced on the GLUT4 and PY20(H) of OIE-treated compared to the untreated-adipocytes. At the same time, the PY20(H) level of OIE-treated was not different from the pre-adipocytes $(P>0.05)$, while the level of PY20(L) of OIE-treated was significantly higher than pre-adipocytes $(P<0.05)$. It was thought that reduced insulin activity

Table 1 Quantitative contents of the main compounds in O. indicum fruit extract determined by LC-MS

\begin{tabular}{llll}
\hline Reference standard & $\begin{array}{l}\text { Retention time } \\
{[\mathbf{1 2}]}\end{array}$ & $\begin{array}{l}\text { Quantitation mass } \\
(\mathbf{m} / \mathbf{z})\end{array}$ & $\begin{array}{l}\text { Concentration in } \mathbf{2 0} \mathbf{~ m g} / \mathbf{m L} \text { of OIE } \\
(\boldsymbol{\mu g} / \mathbf{m L})\end{array}$ \\
\hline Scutellarin & 4.2 & 285 & $\mathrm{ND}$ \\
Daidzein & 10.4 & 253 & $\mathrm{ND}$ \\
Luteolin & 11.4 & 285 & 4.20 \\
Apigenin & 14.6 & 269 & 1.55 \\
Naringenin & 14.7 & 271 & $\mathrm{ND}$ \\
Genistein & 14.8 & 269 & $\mathrm{ND}$ \\
Baicalein & 16.2 & 269 & 509.96 \\
Unknown1 & 19.5 & 538 & - \\
Unknown2 & 21.1 & 254 & - \\
Oroxylin A & 22.0 & 283 & 5.33 \\
\hline
\end{tabular}




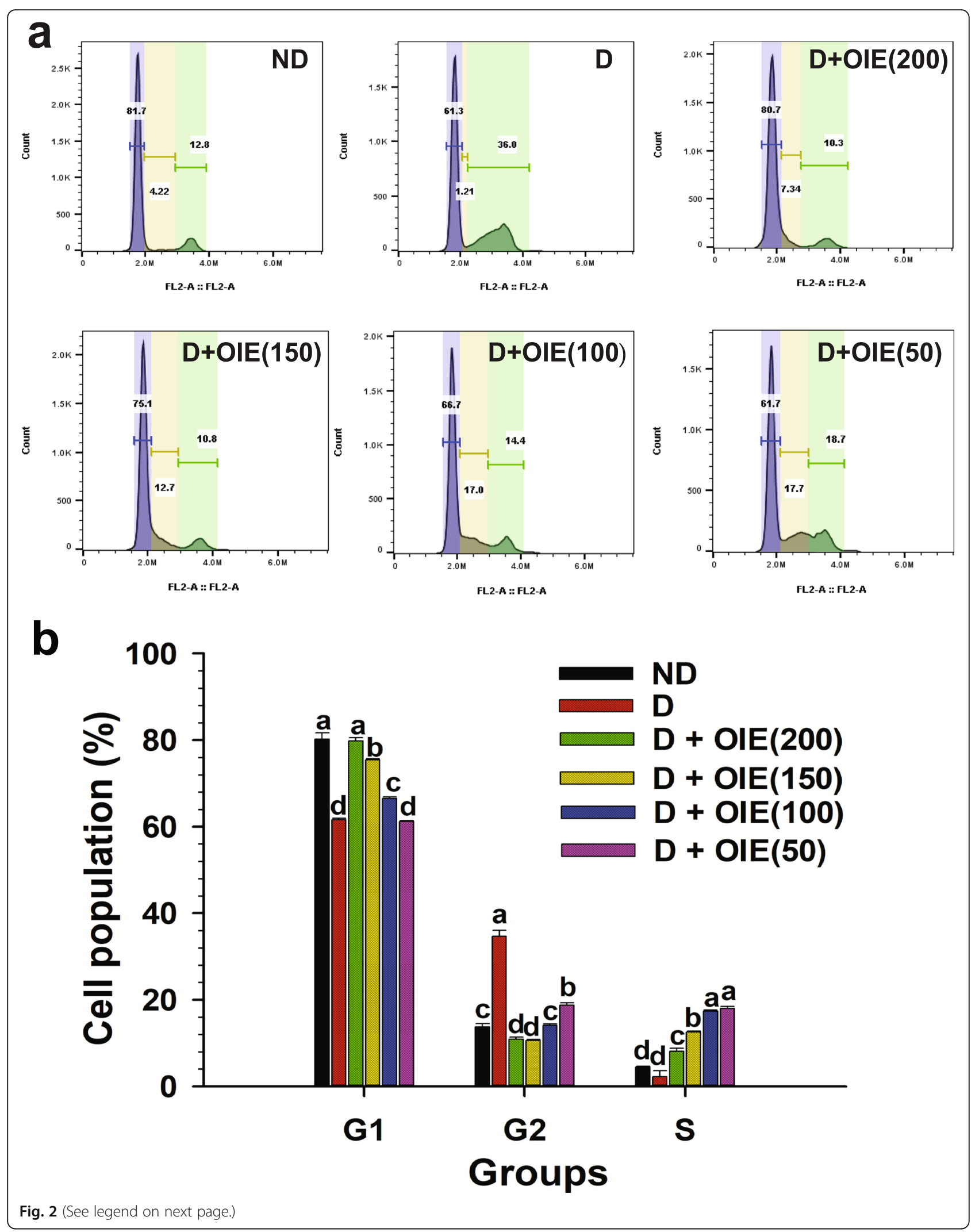


(See figure on previous page.)

Fig. 2 The effect of the OIE on the cell cycle. 3 T3-L1 cells were treated by differentiation media in the presence of OIE at the concentration of 50 to $200 \mu \mathrm{g} / \mathrm{mL}$ for $24 \mathrm{~h}$. The cells were stained with PI and analyzed by flow cytometry for the determination of the cell population. a Flow cytometry data of the cell population in the G0/G1, S, and G2/M phases was determined by Flow Jo software. $\mathbf{b}$ The graph represents the percentage of the cell population. Means \pm SD value $(n=9)$ of three independent experiments is displayed. ND: non-differentiated cells (preadipocytes); D: differentiated cells with 0.1\% DMSO (untreated-adipocytes); D + OIE(200): differentiated cells with OIE at $200 \mu \mathrm{gg} / \mathrm{mL}$ (OIE-treated adipocytes). Differences among groups were determined by one-way ANOVA followed by Tukey's Post-hoc test, and the different superscript alphabets are significantly different from each other $(P<0.05)$

might influence the expression of GLUT4. By day 12 in untreated adipocytes, there was a significant expression of GLUT4 on the plasma membrane (Fig. 5a and b). Treatment with OIE resulted in a $40 \%$ reduction of the GLUT 4 expression compared to untreated adipocytes (Fig. 4a and b). In a parallel experiment, both preadipocytes- and adipocytes-treated with OIE at $200 \mu \mathrm{g} /$ $\mathrm{mL}$ were approximately two folds significantly increased uptake of 2-NBDG compared to both untreated adipocytes at 24 and $48 \mathrm{~h}(P<0.05$, Fig. 6). However, on day 12 , OIE-treated adipocytes were significantly reduced compared to the same groups at $24 \mathrm{~h}$ and $48 \mathrm{~h}(P<$ $0.05)$. One explanation for this is that OIE may diminish the activity of tyrosine kinases leading to a reduction of GLUT4 expression in the plasma. Moreover, the OIE may use the other facilitative glucose transporter, GLUT1 (insulin-independent), which is mostly expressed in pre-adipocytes [17].

\section{Effect of OIE on mitochondrial activity}

The effect of the OIE on mitochondrial activity was evaluated by the MMP, intracellular ATP production,
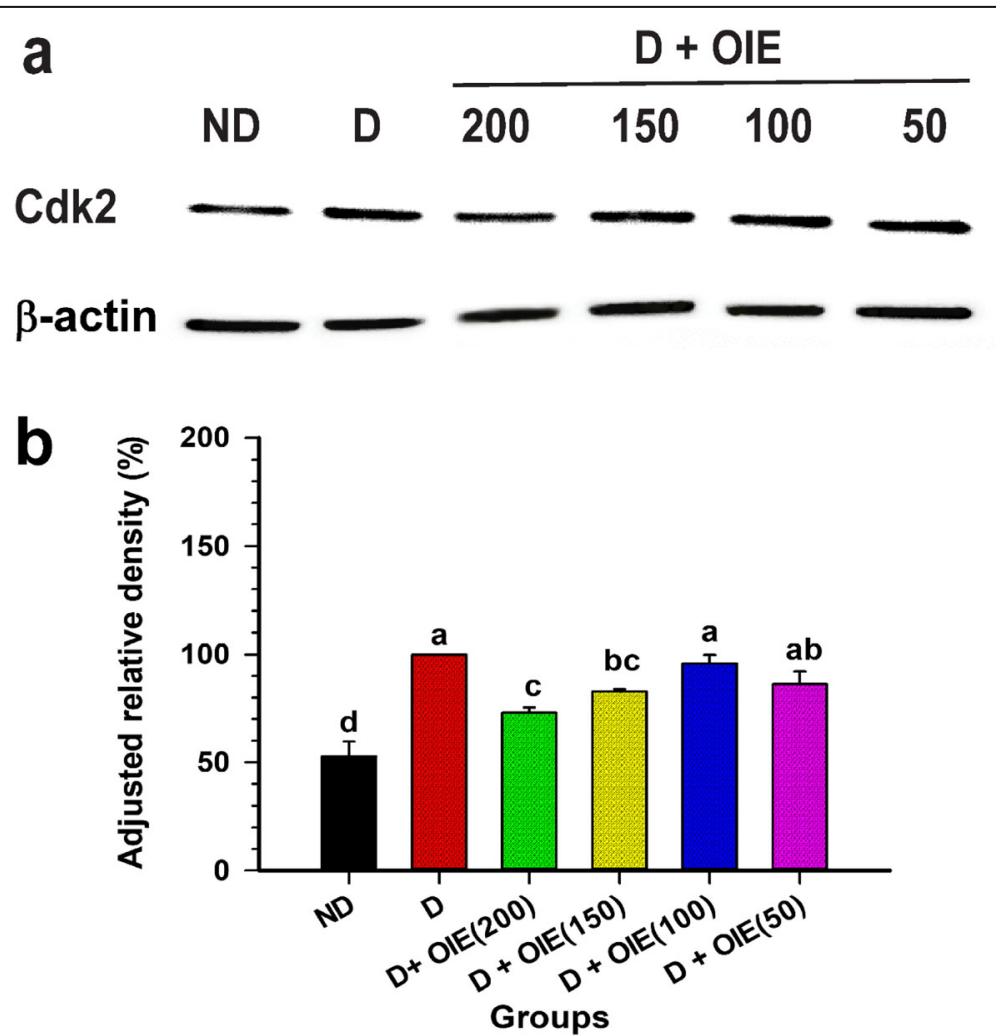

Fig. 3 The effect of the OIE on the expression of Cdk2 in 3T3-L1 cells. a Western blot analysis of the expression of Cdk2 in cells treated with OIE at a concentration range from $50 \mu \mathrm{g} / \mathrm{mL}$ to $200 \mu \mathrm{g} / \mathrm{mL}$ at $24 \mathrm{~h}$. The total lysates of 3 T3-L1 cells with the treatment mentioned above were resolved on Mini-PROTEAN TGX gels followed by transfer to PVDF membrane and probed with the anti-Cdk2 antibody (primary antibody) and secondary antibody. The protein was visualized using chemidoc with the ECL detection kit. $\mathbf{b}$ The densitometry analysis of Western blot bands was normalized against $\beta$-actin and expressed as a mean of \pm SD of three independent experiments $(n=9)$. ND: non-differentiated cells (preadipocytes); D: differentiated cells with 0.1\% DMSO (untreated-adipocytes); D + OIE(200): differentiated cells with OIE at $200 \mu \mathrm{g} / \mathrm{mL}$ (OIE-treated adipocytes). Differences among groups were determined by one-way ANOVA followed by Tukey's Post-hoc test, and the different superscript alphabets are significantly different from each other $(P<0.05)$. The full-length of the blots are presented in Supplementary Figure 1 

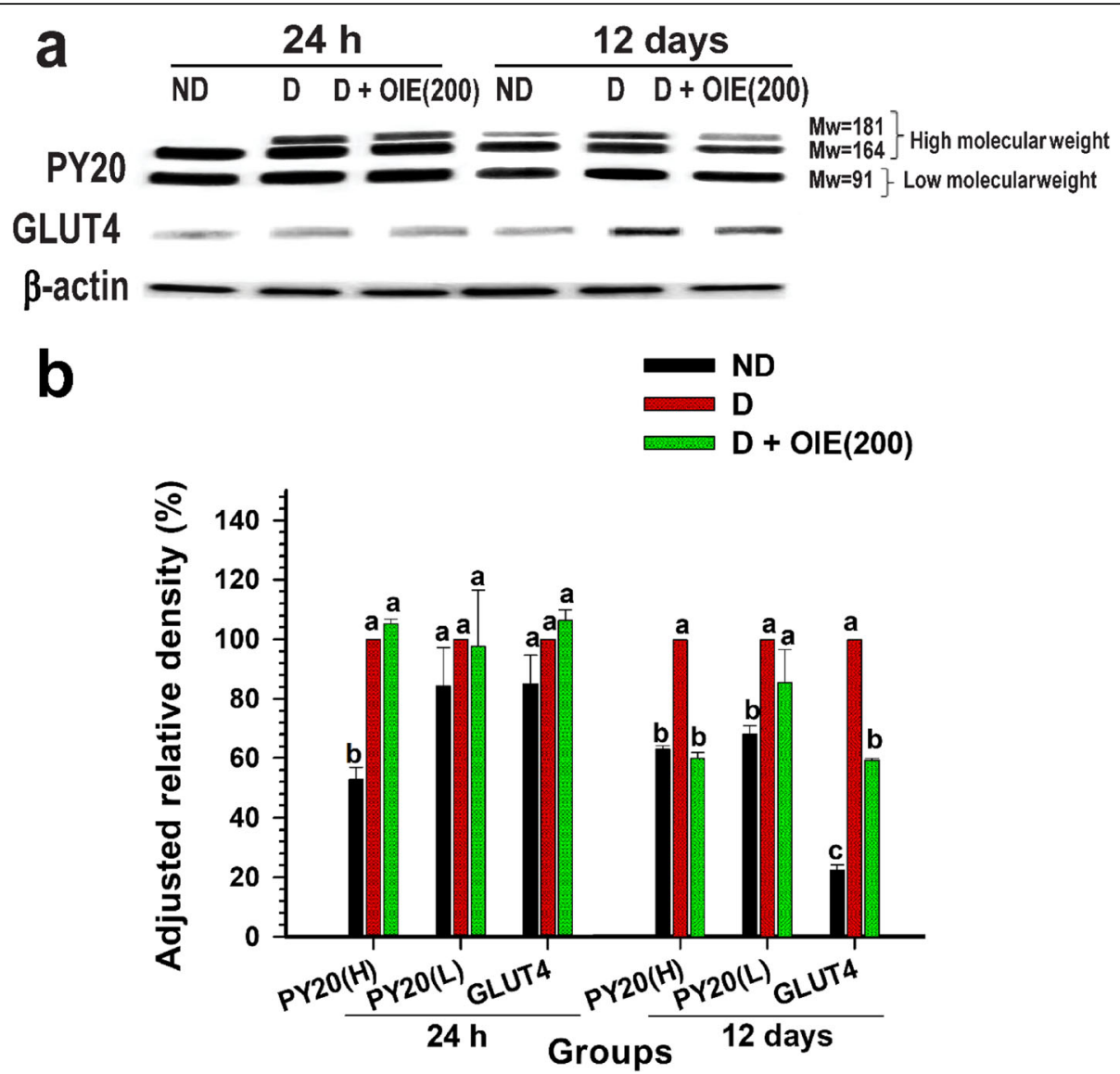

Fig. 4 The effect of OIE on glucose metabolism in 3T3-L1 cells. a Western blot analysis displays the expression of PY20 and GLUT4 in cells treated with $200 \mu \mathrm{g} / \mathrm{mL}$ OIE at $24 \mathrm{~h}$ and 12 days. The total lysates of 3 T3-L1 cells were resolved on Mini-PROTEAN TGX gels followed by transfer to a PVDF membrane, probed with the anti-phosphotyrosine antibody, anti-glucose transporter 4 (primary antibody), and a secondary antibody. The protein was visualized using chemidoc with the ECL detection kit. $\mathbf{b}$ The densitometry analysis of Western blot bands was normalized against $\beta$-actin. Means \pm SD value $(n=9)$ of three independent experiments is presented. PY2O $(H)=$ protein tyrosine phosphorylation with 181 or 164 kDa; PY20(L) = protein tyrosine phosphorylation with 91 kDa; ND: non-differentiated cells (pre-adipocytes); D: differentiated cells with $0.1 \%$ DMSO (untreated-adipocytes); D + OIE(200): differentiated cells with OIE at $200 \mu \mathrm{g} / \mathrm{mL}$ (OIE-treated adipocytes). Differences among groups were determined by one-way ANOVA followed by Tukey's Post-hoc test, and the different superscript alphabets are significantly different from each other $(P<0.05)$. The full-length of the blots are presented in Supplementary Figure 2

mitochondrial mass, and morphology determination. The JC-1 was used for monitoring the mitochondrial membrane. When the dyes enter into the cytoplasm of cells, it exhibits a green fluorescence color called the JC1 monomer. However, when the dyes enter into the mitochondria, it will accumulate and start forming reversible complexes called JC-1 aggregates. These JC-1 aggregates exhibited excitation and emission in the red spectrum. Fluorescence staining showed that JC-1 monomer (green) and JC-1 aggregates (red) were displayed in all samples (Fig. 7). However, JC-1 aggregates in OIE-treated-ND, OIE-treated-D, and ND groups were less pronounced compared to the $\mathrm{D}$ (untreated-adipocytes) group (Fig. 7). This result is consistent with the flow cytometry data regarding MMP. The increase of MMP (red/green fluorescence ratio) was demonstrated in untreated adipocytes, while treatment with $200 \mu \mathrm{g} / \mathrm{mL}$ at $24 \mathrm{~h}$ significantly reduced the ratio $(P<0.05$, Fig. 8$)$. However, a noticeable reduction of MMP was found in all samples at day 12 compared to $24 \mathrm{~h}$, especially in untreated adipocytes. Furthermore, the cellular ATP level was determined on day 12; the highest intracellular concentration of ATP level was found in untreated adipocytes. It was significantly reduced in adipocytes treated with OIE $(P<0.05$, Fig. 9). MitoTracker dyes have been used for detecting a mitochondrial mass. This fluorescent dye is linking to thiol groups in the mitochondria, and it produces green fluorescence under excitation $488 \mathrm{~nm}$. The results showed that untreated adipocytes displayed a decrease in the intensity of the labeling mitochondrial (Fig. 10), whereas the intensity seemed to increase with longer treatments with $200 \mu \mathrm{g} / \mathrm{mL}$ of the OIE. This observation was similar to pre-adipocytes alone or treated with 


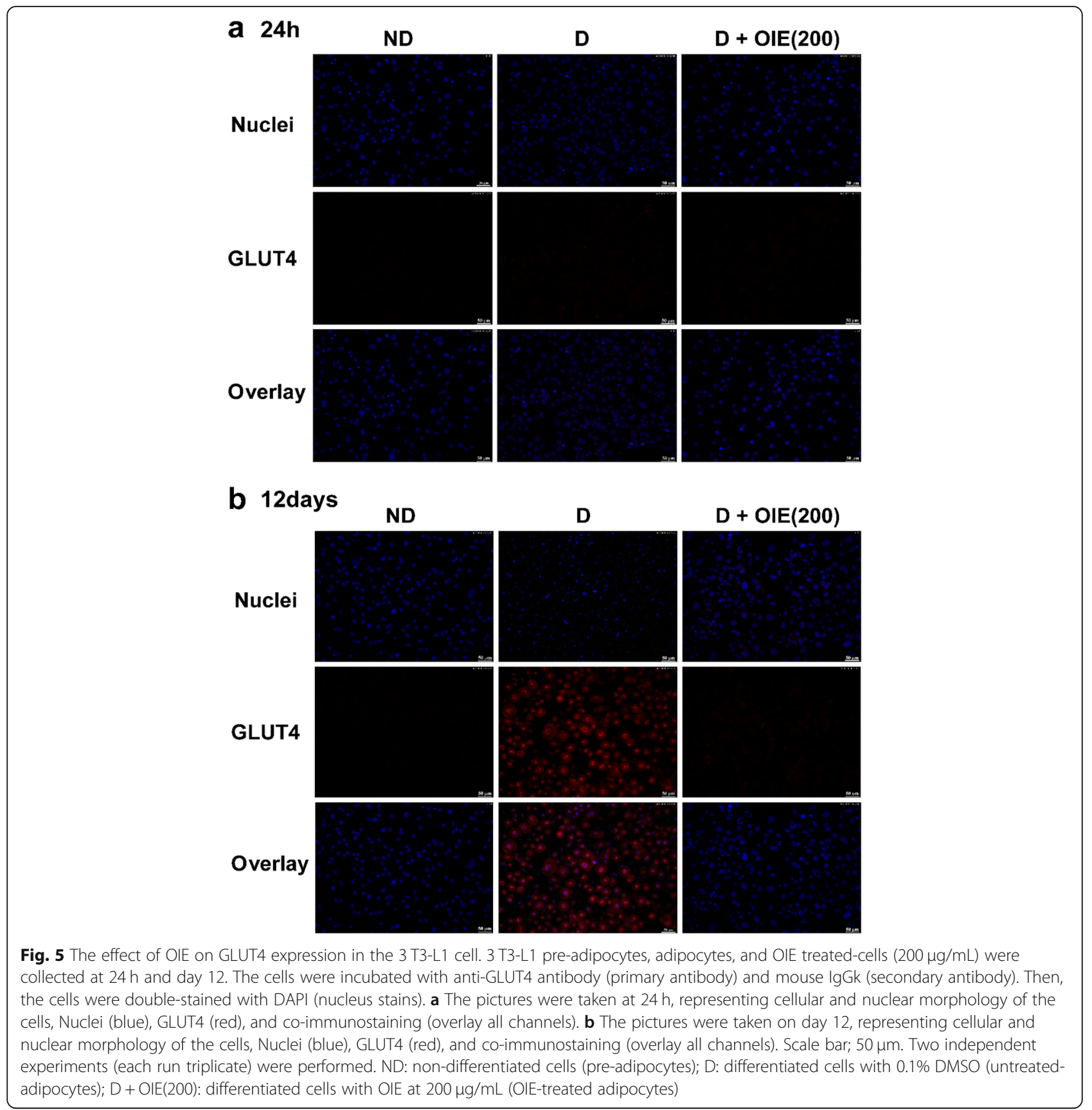

OIE. This study explored the morphology of mitochondria by TEM [18]. The results indicated that mitochondria of pre-adipocytes with and without-OIE were gathered around the nucleus, and the morphology was mainly short, but the cristae were clearly observed (Fig. 11). In contrast, the mitochondria of untreated adipocytes had become a more condensed, slender shape with reduced cristae mitochondria and uniformly distributed in the cytoplasm. While OIEtreated adipocytes could recover mitochondria mass and morphology almost the same as untreated pre- adipocytes. These results suggest that mitochondria play an important role during 3 T3-L1 differentiation. During the adipocyte differentiation process of untreated pre-adipocytes at $24 \mathrm{~h}$, the cells had an increase in MMP. Whereas OIE-treated adipocytes showed significantly lower and higher MMP levels compared to the OIE-untreated adipocytes at $24 \mathrm{~h}$ and day 12 , respectively $(P<0.05$, Fig. 8$)$. However, on day 12, the ATP level of OIE-treated adipocytes was significantly lower compared to non-treated adipocytes $(P<0.05$, Fig. 9$)$. 


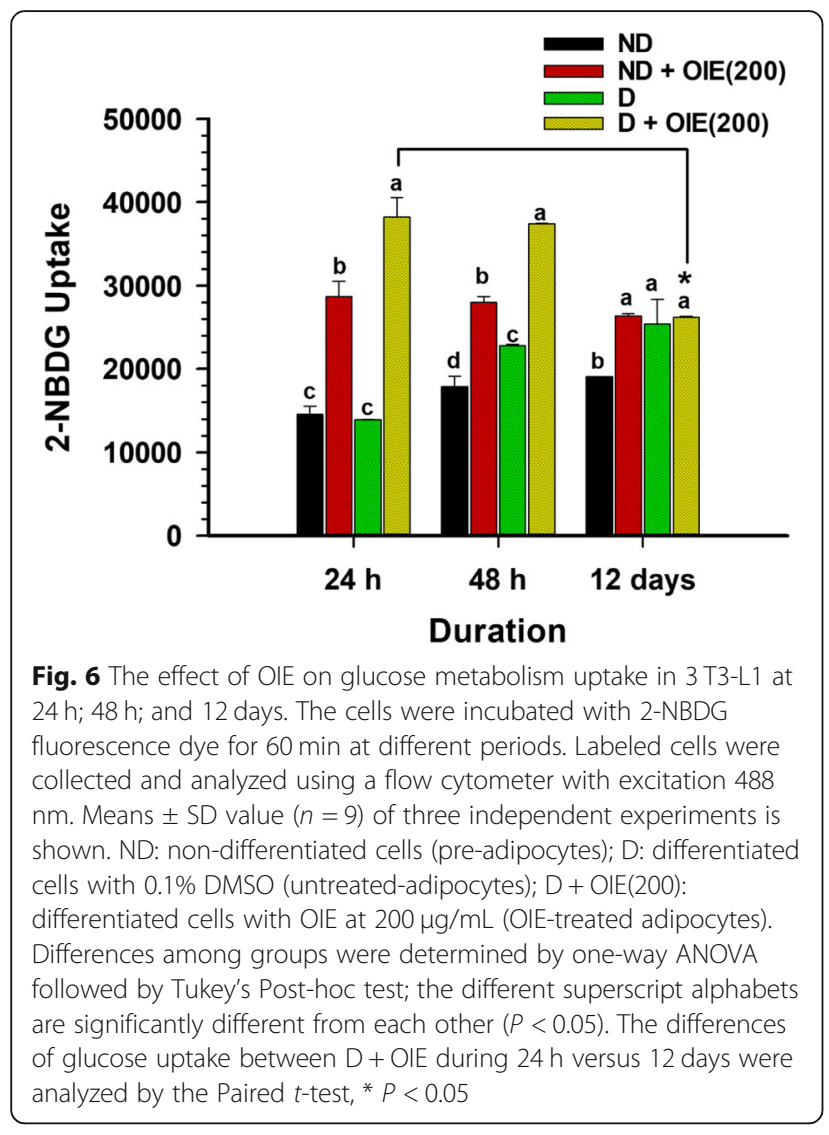

\section{Discussion}

Previous studies reported that OIE had an antiadipogenic effect through inhibiting the expression of PPAR $\gamma$ along with a decrease in adiponectin and FAS production $[8,9]$. In this study, we investigated the impact of the OIE on cell cycle, glucose metabolism, and mitochondria. OIE at doses of $50-200 \mu \mathrm{g} / \mathrm{mL}$ blocked the cell cycle on the G1/S stage at $24 \mathrm{~h}$, and this was

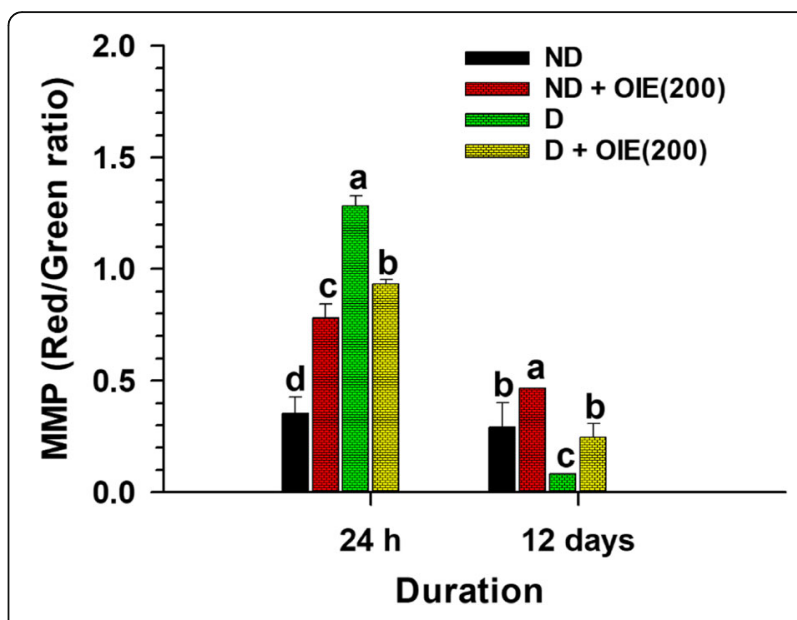

Fig. 8 The effect of OIE on MMP level in 3T3-L1 cells. The cells were incubated with JC-1 fluorescence dye for 60 min at different periods. Labeled cells were collected and analyzed using a flow cytometer with excitation $488 \mathrm{~nm}$. Means \pm SD value $(n=9)$ of three independent experiments is demonstrated. The data were reported as the ratio of red aggregates (FL-2 channel) to green monomer (FL1 channel). ND: non-differentiated cells (pre-adipocytes); ND + OIE(200): non-differentiated cells with OIE at $200 \mu \mathrm{g} / \mathrm{mL}$ (OIE-treated pre-adipocytes); D: differentiated cells with $0.1 \%$ DMSO (untreatedadipocytes); D + OIE(200): differentiated cells with OIE at $200 \mu \mathrm{g} / \mathrm{mL}$ (OlE-treated adipocytes). Differences among groups were determined by one-way ANOVA followed by Tukey's Post-hoc test, and the different superscript alphabets are significantly different from each other $(P<0.05)$

subsequently confirmed by a significant decrease in the expression of $\mathrm{Cdk} 2$, a protein involved in the transition of G1/S to S/G2. Phytochemicals, especially flavonoids, have been shown to processes adipogenesis suppressive in 3 T3-L1 cells. Pretreatment of 3 T3-L1 adipocytes with flavonoids such as baicalein and chrysin suppressed adipogenesis by inducing cell cycle arrest in the G0/G1 phase $[19,20]$. In this study, LC-MS analysis showed

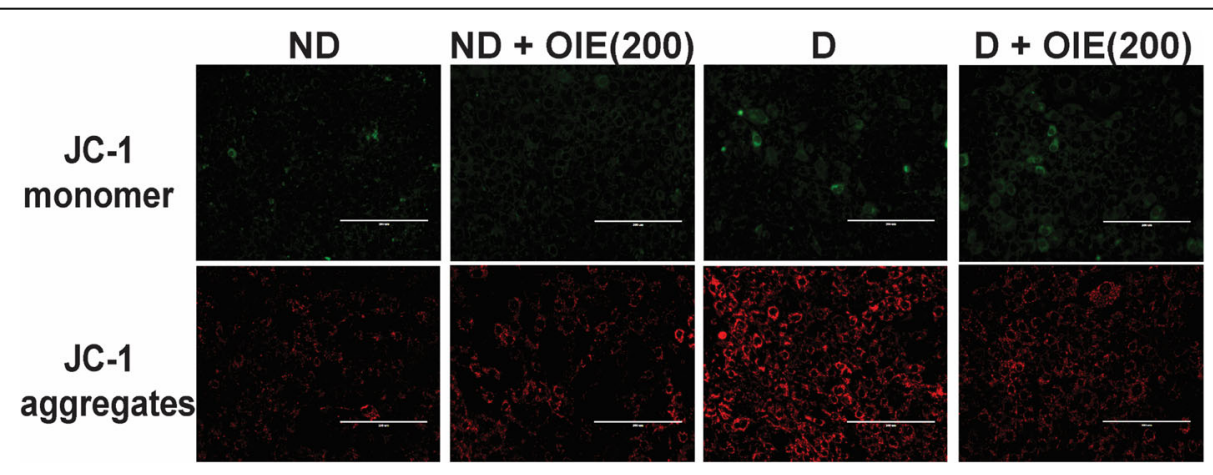

Fig. 7 The effect of OIE on mitochondrial activity in 3T3-L1 at 24 h. The cells were incubated with JC-1 fluorescence dye for 60 min. The images of cells labeled with JC-1 vitalized mitochondria were visualized using fluorescence microscopy, JC-1 monomer is visible as green and aggregates visible as red, scale bar, $200 \mu \mathrm{m}$. Two independent experiments (each run triplicate) were done. ND: non-differentiated cells (pre-adipocytes); ND + OIE(200): non-differentiated cells with OIE at $200 \mu \mathrm{g} / \mathrm{mL}$ (OIE-treated pre-adipocytes); D: differentiated cells with 0.1\% DMSO (untreatedadipocytes), D + OIE(200): differentiated cells with OIE at $200 \mu \mathrm{g} / \mathrm{mL}$ (OIE-treated adipocytes) 


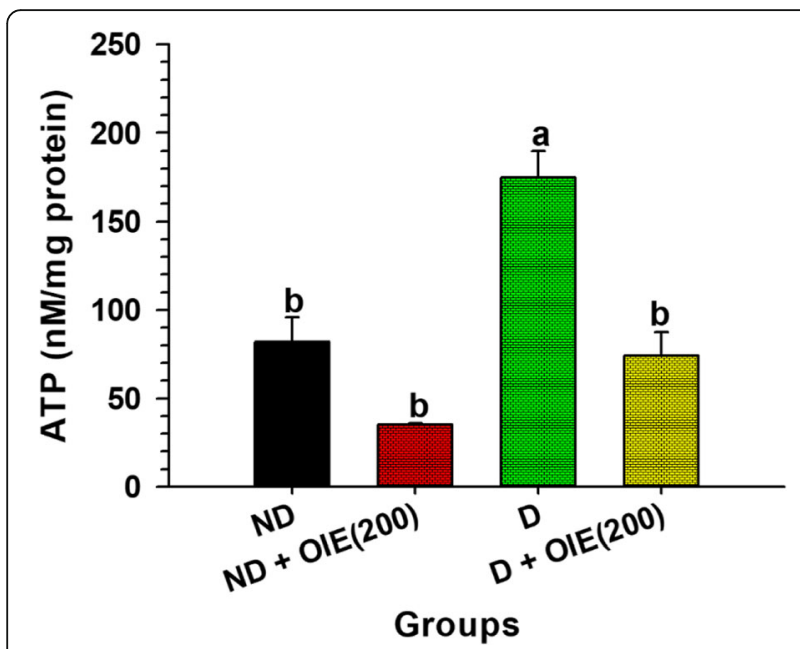

Fig. 9 The effect of OIE on the ATP level at day 12. The level of ATP was determined by ATP bioluminescent. On day 12, the cells were incubated with an ATP releasing agent and transfer to the 96 well plates. The luciferase assay was added to the sample, then the amount of light emission was measured using a microplate luminometer. ATP concentration was determined from the standard curve. The protein concentrations in each group were used to normalize the ATP content ( $\eta \mathrm{M} / \mathrm{mg}$ of protein). Means \pm SD value $(n=9)$ of three independent experiments is indicated. ND: nondifferentiated cells (pre-adipocytes); ND + OIE(200): non-differentiated cells with OIE at $200 \mu \mathrm{g} / \mathrm{mL}$ (OIE-treated pre-adipocytes); D: differentiated cells with $0.1 \%$ DMSO (untreated-adipocytes); D + OIE(200): differentiated cells with OIE at $200 \mu \mathrm{g} / \mathrm{mL}$ (OIE-treated adipocytes). Differences among groups were determined by oneway ANOVA followed by Tukey's Post-hoc test; the different superscript alphabets are significantly different from each other $(P<0.05)$ that baicalein is one of the major components found in OIE. The result of the LC-MS chromatogram at peak 21 ( $\mathrm{m} / \mathrm{z} 254)$ lead us to believe that it could be chrysin, which is consistent with the standard chrysin peak [13]. Thus, it is possible that baicalein and chrysin in OIE responsible for anti-adipogenesis activity by blocking the cell cycle, which is an important adipogenic event at the early stage of cell differentiation. As well as other studies reported that other flavonoids or other chemical compounds inhibited adipocyte differentiation through a similar mechanism $[21,22]$.

The OIE may influence the metabolism of cells during the differentiation process. In order to understand the effect of the OIE glucose uptake and metabolism, this study evaluated the level of tyrosine phosphorylation associated with the IR, GLUT4 expression, and glucose uptake. The results indicated that the protein tyrosine kinase activity was apparent in the differentiated cells with or without OIE at $24 \mathrm{~h}$. However, on day 12, the phosphorylation of proteins with molecular weights (MW) corresponding to 181 and $164 \mathrm{kDa}$ was diminished by treatment with OIE. Whereas, a protein with MW at $91 \mathrm{kDa}$ was not different compared to the untreated adipocytes. The proteins with molecular masses of 181,164 , and $91 \mathrm{kDa}$ correspond to the insulin markers IRS-2, IRS- 1 , and IR $\beta$-subunit, respectively $[15,16,23]$. These results suggest that OIE may influence the activity of insulin and, thus, the uptake of glucose. The increasing phosphorylation of IRS-1 and IRS-2 may activate many different signaling pathways, including phosphatidylinositol-3-kinase (PI3 kinase) and AKT pathway [24]. The activation of PI3 and AKT pathway has been suggested to be a part of the signal transduction pathway for insulin-induced GLUT4 redistribution [18]. This study found that GLUT4 was slightly expressed

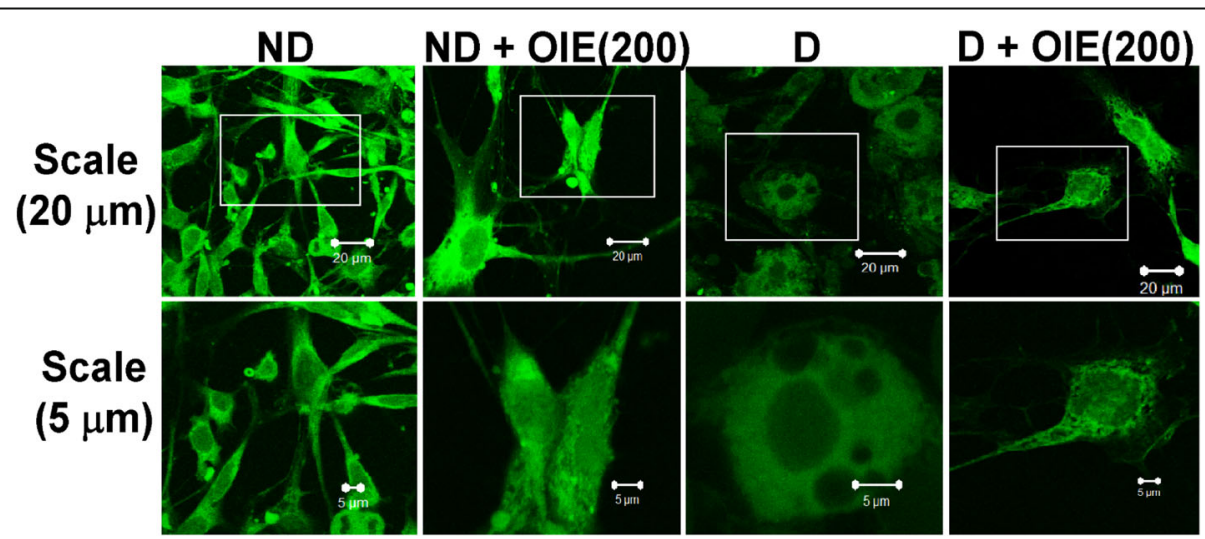

Fig. 10 The effect of OIE on mitochondrial mass. On day 12, the cells were incubated with $200 \mathrm{nM}$ of MitoTracker dyes for 45 min. Labeled cells were transferred to the Shandon cytofunnel chamber and mounted with the mounting media. Then, the cells were visualized by laser scanning microscopy (excitation $488 \mathrm{~nm}$ ). Mitochondria labeled with MitoTracker dyes showed in green color, scale bar, $20 \mu \mathrm{m}$, and $5 \mu \mathrm{m}$. Two independent experiments (each run triplicate) were performed. ND: non-differentiated cells (pre-adipocytes); ND + OIE(200): non-differentiated cells with OIE at $200 \mu \mathrm{g} / \mathrm{mL}$ (OIE-treated pre-adipocytes); D: differentiated cells with 0.1\% DMSO (untreated-adipocytes); D + OIE(200): differentiated cells with OIE at $200 \mathrm{\mu g} / \mathrm{mL}$ (OlE-treated adipocytes) 


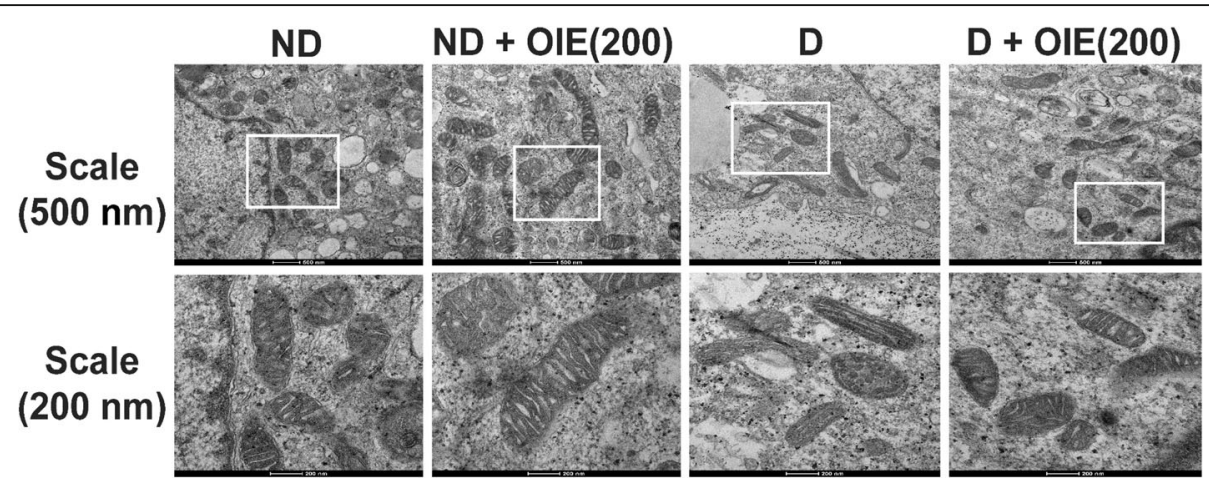

Fig. 11 The effect of OIE on mitochondria morphology. On day 12, the cells were extracted, then fixed in 2.5\% glutaraldehyde, and post-fixated with $1 \%$ Osmium tetroxide. The fixed sample was embedded in epoxy resin. The sample was sectioned at $60 \mathrm{~nm}$ with the ultra-microtome. The sections were stained with $2 \%$ uranyl acetate, followed by secondary staining with lead stain solution. The grids were observed under a TEM at $120 \mathrm{kV}$. The micrographs of mitochondria in 3 T3-L1 cells showed at scale bar $500 \mathrm{~nm}$ and $200 \mathrm{~nm}$. Two independent experiments (each run triplicate) were operated. ND: non-differentiated cells (pre-adipocytes); ND + OIE(200): non-differentiated cells with OIE at $200 \mu \mathrm{gg} / \mathrm{mL}$ (OIE-treated pre-adipocytes); D: differentiated cells with 0.1\% DMSO (untreated-adipocytes); D + OIE (200): differentiated cells with OIE at $200 \mu \mathrm{gg} / \mathrm{mL}$ (OlE-treated adipocytes)

in the same amount in all groups at $24 \mathrm{~h}$. These observations are in substantial agreement with the study of Jackson and colleagues that at the early part of differentiation, the expression of GLUT4 is low but increases reach a peak at day 9 [25]. Similarly, in this investigation, GLUT4 was significantly increased and highly expressed to the cell membrane in untreated adipocytes at day 12 . Whereas, the cells treated with OIE displayed a lower concentration of GLUT4. These findings are likely to believe that the cells are insensitive to insulin and may act on GLUT4 expression and subsequent glucose uptake. One suggestion is that OIE inhibits the phosphorylation of IRS-1 and IRS2, leading to a decrease in GLUT4 protein expression compared to the untreated-adipocytes. If GLUT4 appearance is compromised, this would have an impact on glucose uptake and intracellular glucose concentrations. Moreover, in this study, we found that the OIE treated pre-adipocytes and adipocytes significantly increased glucose uptake level by approximately 2 folds compared to both untreated cells with no effect on GLUT4 expression. This may be explained as cells treated with OIE may use another facilitative transporter-like GLUT1 and is less dependent on GLUT4. In fact, the abundance of GLUT1 was found in 3 T3-L1 cells at the pre-adipocytes stage and diminished when cells become adipocytes [26]. Besides, in adipose tissue, GLUT1 is expressed along with GLUT4. However, GLUT4, which is insulin-dependent, are more dominantly expressed in adipose tissue than the GLUT1 [27]. Some of the antidiabetic drugs, such as rosiglitazone, enhanced glucose transport in the basal stage caused by an increase in the synthesis of GLUT1 RNA and protein [28]. Furthermore, thiazolidinediones in both basal and insulin stages increase the glucose uptake and cellular GLUT1 expression with no effect on GLUT4 expression $[28,29]$. Another study also demonstrated that 3 T3-L1 cells treated with $50 \mu \mathrm{M}$ of baicalein significantly suppressed the expression of the GLUT4 gene and decreased the glucose uptake level [30]. Moreover, it had been reported that $100 \mathrm{mg} / \mathrm{kg}$ body weight of chrysin inhibited insulin receptor 1 (IR1) gene expression and contributed to the reduction of IR1 protein in diabetic rats [31]. Also, Berberine is a major alkaloid component of Rhizoma coptidis, has shown a promising impact on the upregulation of GLUT-1 expression level by stimulating the extracellular signal-regulated kinases (ERK) pathway in $3 \mathrm{~T} 3-\mathrm{L} 1$ cells $[32,33]$.

Previous studies had demonstrated that during adipogenesis, mitochondria were present at number 19 folds greater than 3 T3-L1 pre-adipocytes [34]. Similarly, this investigation found that the level of MMP in untreatedadipocytes was significantly increased during the first 24 h compared to the pre-adipocytes (Fig. 8). However, on day 12, the MMP level of the untreated-adipocytes was dramatically decreased compared to the pre-adipocytes (Fig. 8), while the ATP level increased compared to preadipocytes (Fig. 9). Additionally, confocal microscopy revealed that the adipocytes' mitochondria displayed pale green fluorescence, which represents the mitochondrial mass. Moreover, the morphology of adipocytes' mitochondria was elongated. This finding is consistent with the previous study that during differentiation, the mitochondria continuously switch their morphology from globular to elongated mitochondria via mitochondrial fusion [12]. Accordingly, mitochondria undergo dynamic remodeling during differentiation, and thus, mitochondrial morphology and metabolism are changed. Although a massive increase in the number and activity of mitochondria beginning in the early adipogenesis [35]. This change is because mitochondria provide the essential substrate necessary for lipogenesis [36]. However, 
the study of Goldman and colleagues confirmed that mature adipocytes contained very few mitochondria compared to the cells undergoing in the differentiation process [37]. The decreasing of mitochondria content likely reflects the decreased need for lipogenesis in the mature white adipocyte. Likewise, the changing of mitochondria morphology could disrupt their function [34, $38,39]$. In the same way, the altered mitochondrial morphology in adipocytes was observed in this study. A previous study revealed that phytochemical compounds, including apigenin and quercetin, significantly protected mitochondrial alterations during ER stress in $3 \mathrm{~T} 3-\mathrm{L} 1$ adipocytes [40]. These findings provide evidence that apigenin and other flavonoids found in OIE may play a vital role in mitochondria protection. Thus, these findings lend support to the assumption that at the early phase of differentiation, untreated differentiated cells need a lot of ATP production for lipogenesis as shown by increasing of MMP level at $24 \mathrm{~h}$, while the fusion of adipocytes mitochondria at day 12 takes effect to the mitochondria activity results in a decrease in the MMP level. Apart from this, an increasing ATP level in adipocytes might be explained hypothesizing that the mitochondria have been compromised, and then, the cell switches to glycolysis. However, ATP generated from the glycolysis pathway may not be enough for the cells. Thus, the cells try to keep homeostasis by increasing glucose uptake levels. On the contrary, OIE-treated adipocytes exhibited significantly lower and higher MMP levels at $24 \mathrm{~h}$ and 12 days, respectively, which use lower ATP like pre-adipocytes. Moreover, the mitochondria mass and morphology of the OIE-treated cells are virtually similar to preadipocytes mitochondria.

\section{Conclusion}

In this study, we clarified that the anti-adipogenic activity of OIE was achieved through the inhibition of cell cycle progression and reduced the expression of IR protein resulted in a decrease in the glucose uptake level. Furthermore, OIE slowed down the mitochondrial activity of the early phase of cell differentiation, caused lipogenesis reduction, which was similar to the preadipocytes stage.

\section{Supplementary information}

The online version contains supplementary material available at https://doi. org/10.1186/s12906-020-03111-2.

Additional file 1. The results of western blots analysis. Figure S1. Full range of the expression of cyclin-dependent kinase 2 (Cdk2) and beta actin ( $\beta$-actin) in 3T3-L1 cells. Figure S2. Full range of the expression of glucose transporter4 (Glut4), protein tyrosine phosphorylation (PY20) and beta actin ( $\beta$-actin) in 3T3-L1 cells. (ZIP 1234 kb)

\section{Abbreviations}

OlE: Oroxylum indicum fruit extract; 0 . indicum: Oroxylum indicum; Cdk2: Cyclin-dependent kinase 2; GLUT4: Glucose transporter4; PY20: Protein tyrosine phosphorylation; MMP: Mitochondrial membrane potential; IR: Insulin receptor; IRS: Insulin receptor substrate; ATP: Adenosine triphosphate; LC-MS: Liquid chromatography-mass spectrometry; DMSO: Dimethyl sulfoxide; ND: Non-differentiated cells (pre-adipocytes); D: Differentiated cells with $0.1 \%$ DMSO (untreated-adipocytes); D + OIE(200): Differentiated cells with OIE at $200 \mu \mathrm{g} / \mathrm{mL}$ (OIE-treated adipocytes); 2-NBDG: 2-deoxy-2-[(7-nitro-2,1,3-benzoxadiazol-4-yl)amino]-D-glucose; MCE: Mitotic clonal expansion; PI: Propidium iodide; ECL: Enhanced chemiluminescence; DMEM: Dulbecco's Modified Eagle Medium; FBS: Fetal bovine serum; IBMX: 3-isobutyl-1-methylxanthine; DEX: Dexamethasone; PVDF: Polyvinylidene difluoride; HRP: Horseradish peroxidase; PBST: PBS with 0.1\% Tween 20; BSA: Bovine serum albumin; FITC: Fluorescein isothiocyanate; DAPI: 4',6-Diamidino-2-Phenylindole; PBS: Phosphate-buffered saline; JC-

1: Fluorescent lipophilic carbocyanine dye; PI3 kinase: Phosphatidylinositol-3kinase; ERK: Extracellular signal-regulated kinases

\section{Acknowledgments}

The authors thank the Thailand Research Fund for financially supported. We thank Dr. Kate Phillips, Dr. Darren Sexton, and Dr. Mark Murphy for providing fluorescent tracers and technical advice.

\section{Authors' contributions}

Conceptualization: TH, GL and GE; methodology: TH and GL; formal analysis: $\mathrm{TH}$ and $\mathrm{GE}$; investigation: $T H$ and $G L$; data curation: $T H, G L$ and $G E ;$ writing original draft preparation: $\mathrm{TH}$; writing review and editing: $\mathrm{TH}, \mathrm{GL}$ and GE; visualization: GL; supervision: GL and GE; project administration: GE; funding acquisition: GE. All authors have read and approved the manuscript.

\section{Funding}

This research was funded by the Thailand Research Fund through The Royal Golden Jubilee Ph.D. Program, grant number PHD/0029//2556. The funder had no role in study design, data collection, and analysis, decision to publish, or preparation of the manuscript.

\section{Availability of data and materials}

The datasets used and/or analyzed during the current study available from the corresponding author on reasonable request.

Ethics approval and consent to participate

This article does not contain any studies with human participants or animals performed by any of the authors.

Consent for publication

All authors consent to publish this study in BMC Complementary Medicine and Therapies.

\section{Competing interests}

The authors declare that they have no competing interests.

Received: 1 September 2020 Accepted: 8 October 2020

Published online: 20 October 2020

\section{References}

1. Ruiz-Ojeda FJ, Ruperez Al, Gomez-Llorente C, Gil A, Aguilera CM. Cell models and their application for studying adipogenic differentiation in relation to obesity: A review. Int J Mol Sci. 2016;17(7):1040.

2. Ailhaud G, Dani C, Amri EZ, Djian P, Vannier C, Doglio A, Forest C, Gaillard D, Négrel R, Grimaldi P. Coupling growth arrest and adipocyte differentiation. Environ Health Perspect. 1989;80:17-23.

3. Camp HS, Ren D, Leff T. Adipogenesis and fat-cell function in obesity and diabetes. Trends Mol Med. 2002:8(9):442-7.

4. Garcia de Herreros A, Birnbaum MJ. The acquisition of increased insulinresponsive hexose transport in 3T3-L1 adipocytes correlates with expression of a novel transporter gene. J Biol Chem. 1989;264(33):19994-9.

5. Deshmukh AS. Insulin-stimulated glucose uptake in healthy and insulinresistant skeletal muscle. Horm Mol Biol Clin Investig. 2016;26(1):13-24.

6. Bertram R, Gram Pedersen M, Luciani DS, Sherman A. A simplified model for mitochondrial ATP production. J Theor Biol. 2006;243(4):575-86. 
7. Wilson-Fritch L, Burkart A, Bell G, Mendelson K, Leszyk J, Nicoloro S, Czech $\mathrm{M}$, Corvera S. Mitochondrial biogenesis and remodeling during adipogenesis and in response to the insulin sensitizer rosiglitazone. Mol Cell Biol. 2003;23(3):1085-94.

8. Hengpratom T, Lowe GM, Thumanu K, Suknasang S, Tiamyom K, Eumkeb G. Oroxylum indicum (L.) Kurz extract inhibits adipogenesis and lipase activity in vitro. BMC Complement Altern Med. 2018;18(1):177.

9. Hengpratom T, Ngernsoungnern A, Ngernsoungnern P, Lowe GM, Eumkeb G. Antiadipogenesis of Oroxylum indicum (L.) Kurz extract via PPARg2 in 3T3L1 adipocytes. Evid Based Complement Alternat Med. 2020;2020:10.

10. Dunkhunthod B, Thumanu K, Eumkeb G. Application of FTIR microspectroscopy for monitoring and discrimination of the antiadipogenesis activity of baicalein in 3T3-L1 adipocytes. Vib Spectrosc. 2017; 89:92-101.

11. Kapoore RV, Coyle R, Staton CA, Brown NJ, Vaidyanathan S. Influence of washing and quenching in profiling the metabolome of adherent mammalian cells: a case study with the metastatic breast cancer cell line MDA-MB-231. Analyst. 2017;142(11):2038-49.

12. Lee JE, Seo BJ, Han MJ, Hong YJ, Hong K, Song H, Lee JW, Do JT. Changes in the expression of mitochondrial morphology-related genes during the differentiation of murine embryonic stem cells. Stem Cells Int. 2020;2020: 9369268.

13. Chen LJ, Games DE, Jones J. Isolation and identification of four flavonoid constituents from the seeds of Oroxylum indicum by high-speed countercurrent chromatography. J Chromatogr A. 2003;988(1):95-105.

14. Rojsanga P, Bunsupa S, Sithisarn P. Flavones contents in extracts from Oroxylum indicum seeds and plant tissue cultures. Molecules. 2020;25(7): 1545.

15. Dupont J, Derouet M, Simon J, Taouis M. Nutritional state regulates insulin receptor and IRS-1 phosphorylation and expression in chicken. Am J Physiol Endocrinol Metab. 1998;274(2):E309-16.

16. Miki H, Yamauchi T, Suzuki R, Komeda K, Tsuchida A, Kubota N, Terauchi Y, Kamon J, Kaburagi Y, Matsui J, et al. Essential role of insulin receptor substrate 1 (IRS-1) and IRS-2 in adipocyte differentiation. Mol Cell Biol. 2001; 21(7):2521-32.

17. Al-Makdissy N, Younsi M, Pierre S, Ziegler O, Donner M. Sphingomyelin/ cholesterol ratio: an important determinant of glucose transport mediated by GLUT-1 in 3T3-L1 preadipocytes. Cell Signal. 2003;15(11):1019-30.

18. Hajiaghaalipour F, Khalilpourfarshbafi M, Arya A. Modulation of glucose transporter protein by dietary flavonoids in type 2 diabetes mellitus. Int J Biol Sci. 2015;11(5):508-24.

19. Seo M-J, Choi H-S, Jeon H-J, Woo M-S, Lee B-Y. Baicalein inhibits lipid accumulation by regulating early adipogenesis and $m-T O R$ signaling. Food Chem Toxicol. 2014;67:57-64.

20. Gao M, Ding ZS, Shui YM, Zhou FM, Gao JL. Chrysin inhibits adipogenic differentiation of mouse embryonic fibroblasts. Chin Mater Med. 2016:41(1): 106-11.

21. Khalilpourfarshbafi M, Gholami K, Murugan DD, Abdul Sattar MZ, Abdullah NA. Differential effects of dietary flavonoids on adipogenesis. Eur J Nutr. 2019;58(1):5-25.

22. Tang QQ, Otto TC, Lane MD. Mitotic clonal expansion: a synchronous process required for adipogenesis. Proc Natl Acad Sci U S A. 2003;100(1):44-9.

23. Eldar-Finkelman $\mathrm{H}$, Krebs EG. Phosphorylation of insulin receptor substrate 1 by glycogen synthase kinase 3 impairs insulin action. Proc Natl Acad Sci U S A. 1997;94(18):9660-4.

24. Siddle K. Molecular basis of signaling specificity of insulin and IGF receptors: neglected corners and recent advances. Front Endocrinol (Lausanne). 2012; 3:34.

25. Jackson RM, Griesel BA, Gurley JM, Szweda LI, Olson AL. Glucose availability controls adipogenesis in mouse 3T3-L1 adipocytes via up-regulation of nicotinamide metabolism. J Biol Chem. 2017;292(45):18556-64.

26. Ziehm D, Schürmann A, Weiland M, Joost HG. Biphasic alteration of glucose transport in $3 T 3-\mathrm{L} 1$ cells during differentiation to the adipocyte-like phenotype. Horm Metab Res. 1993;25(2):71-6.

27. Shetty M, Loeb JN, Vikstrom K, Ismail-Beigi F. Rapid activation of GLUT-1 glucose transporter following inhibition of oxidative phosphorylation in clone 9 cells. J Biol Chem. 1993;268(23):17225-32.

28. Ciaraldi T, Henry RR. Thiazolidinediones and their effects on glucose transporters. Eur J Endocrinol. 1997;137(6):610-2.

29. Nugent C, Prins JB, Whitehead JP, Savage D, Wentworth JM, Chatterjee VK, O'Rahilly S. Potentiation of glucose uptake in 3T3-L1 adipocytes by PPAR gamma agonists is maintained in cells expressing a PPAR gamma dominant-negative mutant: evidence for selectivity in the downstream responses to PPAR gamma activation. Mol Endocrinol. 2001;15(10):1729-38.

30. Nakao $Y$, Yoshihara $H$, Fujimori K. Suppression of very early stage of adipogenesis by baicalein, a plant-derived flavonoid through reduced AktC/EBPa-GLUT4 signaling-mediated glucose uptake in 3T3-L1 adipocytes. PLoS One. 2016;11(9):e0163640.

31. Satyanarayana K, Sravanthi K, Shaker IA, Ponnulakshmi R, Selvaraj J. Role of chrysin on expression of insulin signaling molecules. J Ayurveda Integr Med. 2015;6(4):248-58.

32. Kim SH, Shin EJ, Kim ED, Bayaraa T, Frost SC, Hyun CK. Berberine activates GLUT1-mediated glucose uptake in 3T3-L1 adipocytes. Biol Pharm Bull. 2007;30(11):2120-5.

33. Cok A, Plaisier C, Salie MJ, Oram DS, Chenge J, Louters LL. Berberine acutely activates the glucose transport activity of GLUT1. Biochimie. 2011;93(7): 1187-92.

34. Kim BW, Choo HJ, Lee JW, Kim JH, Ko YG. Extracellular ATP is generated by ATP synthase complex in adipocyte lipid rafts. Exp Mol Med. 2004;36(5):476-85.

35. Kaaman M, Sparks LM, van Harmelen V, Smith SR, Sjolin E, Dahlman I, Arner $P$. Strong association between mitochondrial DNA copy number and lipogenesis in human white adipose tissue. Diabetologia. 2007;50(12):2526-33.

36. Rosen ED, Spiegelman BM. Adipocytes as regulators of energy balance and glucose homeostasis. Nature. 2006:444(7121):847-53.

37. Goldman SJ, Zhang Y, Jin S. Autophagic degradation of mitochondria in white adipose tissue differentiation. Antioxid Redox Signal. 2011;14(10): 1971-8.

38. Cogliati S, Enriquez JA, Scorrano L. Mitochondrial cristae: where beauty meets functionality. Trends Biochem Sci. 2016;41(3):261-73.

39. Hackenbrock CR. Ultrastructural bases for metabolically linked mechanical activity in mitochondrial reversible ultrastructural changes with change in metabolic steady state in isolated liver mitochondria. J Cell Biol. 1966;30(2): 269-97.

40. Nisha VM, Anusree SS, Priyanka A, Raghu KG. Apigenin and quercetin ameliorate mitochondrial alterations by tunicamycin-induced ER stress in 3T3-L1 adipocytes. Appl Biochem. 2014;174(4):1365-75.

\section{Publisher's Note}

Springer Nature remains neutral with regard to jurisdictional claims in published maps and institutional affiliations.

Ready to submit your research? Choose BMC and benefit from:

- fast, convenient online submission

- thorough peer review by experienced researchers in your field

- rapid publication on acceptance

- support for research data, including large and complex data types

- gold Open Access which fosters wider collaboration and increased citations

- maximum visibility for your research: over $100 \mathrm{M}$ website views per year

At $\mathrm{BMC}$, research is always in progress.

Learn more biomedcentral.com/submissions 